\title{
Efficient treatment of banking services under VAT
}

\author{
Guillermo Peña* \\ Department of Public Economics, University of Zaragoza, Zaragoza, Spain
}

Received: 12 February 2019

Revised: 6 July 2019

Accepted: 16 September 2019

\begin{abstract}
The efficiency of tax systems is an important topic for policy makers and academics. We focus on the efficiency of applying VAT to traditional banking services, a significant issue where a consensus has yet to be reached since the first debates more than two decades ago. This paper discusses one of the most relevant models of tax efficiency on banking services under VAT, the model developed by Jack (2000). This author shows that explicit fees and commissions should be taxable under VAT, while implicit fees covered by banking spreads should be zerorated. An alternative theoretical approach is developed in this paper, proposing the taxation of both explicit and implicit fees of financial services under VAT at the same tax rate, which should also be the same rate applied to all other goods and services.
\end{abstract}

Keywords: value added tax; financial services; tax efficiency

JEL Classification Codes: E21, G21, H21

\section{Introduction}

The efficient taxation of traditional banking services (savings and loans) under VAT has been discussed for over two decades without reaching a consensus. Value added tax (VAT) has been implemented in more than 150 countries since the 1960s. However, in most countries, financial services are exempt from VAT. López-Laborda and Peña $(2017,2018)$ review the main arguments for the exemption. Some economists suggest that taxation of intermediation charges (fees and commissions) could lead to double taxation of savings, but they are considering financial charges as part of savings, not consumption. Another argument is the difficulty in observing or measuring these charges. Finally, even if observable, there is a factual barrier on the accurate allocation of these charges among consumers. These two last reasons are what make this type of taxation so complex.

Nonetheless, the exemption of financial services from VAT leads to many distortions, as López-Laborda and Peña (2017) show. One issue is that VAT on purchases by financial companies cannot be recovered, which breaks the VAT chain, and leads to tax cascading because

\footnotetext{
*E-mail: gpenablasco@gmail.com.

Citation: Peña, G. (2019) Efficient treatment of banking services under VAT, Economics and Business Letters, 8(2), 115-121.
}

DOI: 10.17811/ebl.8.2.2019. 115-121 
companies add this amount to the final price, directly impacting customers. Even taking into account tax incidence, this fact may lead to over-taxation of business customers but undertaxation of households, because they do not pay any explicit tax for consuming financial services, despite the higher price due to tax cascading. There are also incentives to outsourcing or vertical integration in order to avoid irrecoverable input VAT. Exemption also entails compliance costs, because distinguishing between exempt and non-exempt transactions makes taxation more complex and generates problems of interpretation when determining the scope of the exemption and calculating the amount of the recoverable and irrecoverable input VAT. Finally, exemption has negative effects on tax revenue, income distribution, tax avoidance, and economic stability (IMF, 2010).

These distortions have encouraged in-depth discussion among academicians in search of the most accurate method for taxing financial services under VAT. A central issue in this debate is which charges on banking services should be taxed and what their tax rate should be. Jack (2000) develops an inter-temporal consumption model, in which he shows that while explicit charges should be taxed, the taxation of implicit fees would distort the inter-temporal relative prices.

In this paper, we develop an alternative theoretical approach to that of Jack (2000), concluding that both explicit fees and commissions and banking spreads should be taxed, applying the same tax rate to all banking and real consumption.

The paper is organized as follows. The second section presents the model developed by Jack (2000), while the third section proposes an alternative model as an attempt to improve on the previous one. Finally, the fourth section provides the main conclusions.

\section{The taxation of explicit and implicit commissions under VAT: The approach of Jack (2000)}

While most academicians suggested fully taxing all banking charges of financial services (Hoffman, Poddar and Whalley, 1987; Gillis, 1990; English and Poddar, 1997), there was no definitive analytical model analyzing this issue and explicitly considering banking services as output for households in the model. In fact, Auerbach and Gordon (2002) analytically show that the presumption about "all primary inputs that enter into the production of a good should be taxed" is right even for financial services. They consider an explicit treatment of the costs of financial transactions. This financial transaction is an input for a business producing real goods, but not a good by itself. Hence, we observe that they may not explicitly consider banking services as final consumer goods, at least as far as we will aim to do. Even if Auerbach and Gordon (2002) considered financial services as final goods, they only explicitly consider real resources as real costs of conserving bank branches or ATM machines. It seems that they implicitly ignore the presence of non-real inputs as liquidity, safety or others that allow the establishment of some financial services as those Internet-based in which there are insignificant, or almost none, real inputs per financial good, but where there is significant value added generated.

Auerbach and Gordon (2002) show the equivalence between an income and consumption tax. The Financial Activities Tax (FAT) taxes the value added of financial services by levying the sum of profits and remuneration paid by financial institutions. So, income is taxed without looking for the difficult separation between implicit margin and capital income. As Keen, Krelove and Norregaard (2016) state, one of its versions is similar to an addition-based value added tax (VAT). Nonetheless, it is not compatible with a credit-voice VAT, maintaining an exemption that, as Mirrlees state, breaks the VAT chain.

In the context of the USA, where VAT does not apply, Jack (2000) developed a simple twoperiod model with consumption dealing with the taxation of financial services under a broadbased consumption tax. While he considered several types of financial services (banking, insurance, investment funds, etc.), here we focus on traditional banking transactions. We prefer 
to base our model in Jack (2000) instead of Auerbach and Gordon (2002) because, first, the former explicitly treats the implicit margin of banking services. Second, because the latter treat explicitly real inputs but not, as far as we know, the non-real, nonetheless, the former allows us to consider the non-real inputs as part of the implicit margin. At Jack's model, consumption in period $i$ is denoted by $c_{i}, i=1,2$. The purchasing price of good $i$ is $p_{i}$, including all searching costs which the individual could incur. Consumers are net savers, because they receive an exogenous income $w$ in period 1, but income in period 2 is zero, and the consumers deposit their funds with a bank, earning an interest rate free of charge and risk (or "pure" interest) $\varepsilon$ (denoted by $r$ in Jack's terminology). In a scenario of costless banking, the inter-temporal budget constraint would be:

$$
p_{1} c_{1}+\frac{p_{2}}{1+\varepsilon} c_{2}=w
$$

Next, Jack (2000) considers that the transformation of the consumption of the first period on consumption of the second period requires the use of costly banking inputs. The author considers three kinds of costs. For each of those costs, banks apply a distinct charge. There are certain fixed costs linked to banking services, related to opening accounts and maintaining costs. For these costs banks apply a fixed fee $F$ such as annual credit card and account opening fees. There are also convenience components denominated quasi-fixed costs, which are proportional to the volume of transactions, and allow individuals to make payments automatically, or to economize on cash holdings. They are charged through a quasi-fixed fee $\phi$, covering charges such as fees on ATM transactions and bank checks. Finally, there are some proportional costs on the nominal value of the inter-temporal transfer, which represents the bank's loan portfolio not expected to perform or resources devoted to monitoring and supervising larger loans, or marketing to larger depositors. These costs are levied with a proportional fee $\sigma$, identified as the margin or spread of deposits, which is proportional to the nominal value of the deposit funds.

In this scenario with costly banking, the inter-temporal budget constraint is as follows:

$$
\left(p_{1}^{\prime}+\phi\right) c_{1}+\frac{\left(p_{2}{ }_{2}+\phi\right)}{(1+\varepsilon-\sigma)} c_{2}=w-\frac{F \delta}{(1+\varepsilon-\sigma)}
$$

Where $p^{\prime}{ }_{i}$ is the gross price of the good in the period $i$ reduced by banking services included as a convenience component, for which the financial entity establishes an explicit commission $\phi$. The term $\delta=0$ if $c_{2}=0$ and $\delta>0$ if $c_{2}>0$.

So, the relative price of a good in period 2 with respect to a good in period 1 would be:

$$
\tilde{p}_{0}=\frac{\left(p_{2}^{\prime}+\phi\right)}{\left(p_{1}^{\prime}+\phi\right)(1+\varepsilon-\sigma)}
$$

If a tax rate $\tau$ is applied to the purchasing price of goods of the first and second period, we have:

$$
\tilde{p}_{1}=\frac{\left((1+\tau) p_{2}^{\prime}+\phi\right)}{\left((1+\tau) p_{1}^{\prime}+\phi\right)(1+\varepsilon-\sigma)}
$$

Relative price has changed with respect to the baseline scenario [2]:

$$
\tilde{p}_{0} \neq \tilde{p}_{1}
$$

Applying the same tax rate to the price of the goods and to the explicit commission, we obtain:

$$
\tilde{p}_{2}=\frac{\left((1+\tau) p_{2}^{\prime}+(1+\tau) \phi\right)}{\left((1+\tau) p_{1}^{\prime}+(1+\tau) \phi\right)(1+\varepsilon-\sigma)}
$$

This is a neutral tax policy because there is no alteration on inter-temporal relative price:

$$
\tilde{p}_{0}=\tilde{p}_{2}
$$

If the financial margin were also taxed, we obtain: 


$$
\tilde{p}_{3}=\frac{\left((1+\tau) p_{2}^{\prime}+(1+\tau) \phi\right)}{\left((1+\tau) p_{1}^{\prime}+(1+\tau) \phi\right)(1+\varepsilon-(1+\tau) \sigma)}
$$

So, in this model, deposit spreads should not be levied under VAT, because this distorts intertemporal price:

$$
\tilde{p}_{3}>\tilde{p}_{0}
$$

Another interesting question to consider would be the desirability of taxing explicit fees for financial services at the same tax rate as real consumption, which is implicit in Jack's approach, but which we explicitly express by separating in [6] the tax rate for financial services $\left(\tau_{F}\right)$, from the rate of real consumption $\left(\tau_{R}\right)$.

$$
\tilde{p}_{4}=\frac{\left(\left(1+\tau_{R}\right) p_{2}^{\prime}+\left(1+\tau_{F}\right) \phi\right)}{\left(\left(1+\tau_{R}\right) p_{1}^{\prime}+\left(1+\tau_{F}\right) \phi\right)(1+\varepsilon-\sigma)}
$$

If $\tau_{R}=\tau_{F}$, then $\tilde{p}_{4} \neq \tilde{p}_{0}$. Therefore, the tax rate on explicit fees and commissions should be the same as on real goods and services. ${ }^{1}$

This section provides two main conclusions from Jack's model. First, explicit fees and commissions should be taxed at the same tax rate as non-financial consumption. Second, banking spreads should not be taxed.

\section{An alternative theoretical specification}

In Jack's approach, implicit fees for financial services are not considered financial consumption. Nonetheless, in this paper we propose implicit margins to be considered as part of financial consumption. Without banking charges, consumers only save and consume real goods and services, but with costly banking, final households have to renounce some real consumption in order to consume financial services, which allow them to save. So, consumers cut back part of their potential spending on real goods and services to reallocate money to financial consumption, represented by fixed and quasi-fixed fees, and also banking spreads. This financial consumption allows the household to save.

We can write the budget constraints of period 1 and 2, respectively, as follows:

$$
\begin{aligned}
& w=p^{\prime}{ }_{1} c_{1}+s_{1} \\
& s_{1}(1+\varepsilon)=p^{\prime}{ }_{2} c_{2}+\sigma p^{\prime}{ }_{2} c_{2}+\phi c_{2}+F \delta
\end{aligned}
$$

Where savings from the first period $s_{1}$, capitalized for the second period, are equal to the real consumption of the second period $p_{2}{ }_{2} c_{2}$, and this consumption is reduced due to the financial consumption, which is equal to the spread charge $\left(\sigma p^{\prime}{ }_{2} c_{2}\right)$, which would also include the value of non-real inputs as the satisfaction of safety and liquidity needs, the quasi-fixed fee $\left(\phi c_{2}\right)$, and the fixed fee $(F \delta)$. In this implicit fee non-real inputs as security or money availability could be incorporated, in contrast to Jack (2000) or Auerbach and Gordon (2002), who do not explicitly consider non-real inputs. Hence, the implicit margin is considered as financial consumption and reduces the total amount of real consumption proportionally to the spread. The reason is that some part of the household's budget constraint is used to pay the financial services as final goods, which reduces their purchase power of other final goods as real consumption. Based on [11], we can re-write the inter-temporal budget constraint obtained by Jack (2000) in [2] as follows:

$$
\left(p_{1}^{\prime}+\phi\right) c_{1}+\frac{\left((1+\sigma) p_{2}^{\prime}+\phi\right)}{(1+\varepsilon)} c_{2}=w-\frac{F \delta}{(1+\varepsilon)}
$$

\footnotetext{
${ }^{1}$ Recently, Lockwood and Yerushalmi (2014) suggest that taxing transaction services provided by banks at the same tax rate as consumption is an optimal structure, but only when cash is not available, because if cash is available, a cash transaction could distort the choice of the means of payment.
} 
The inter-temporal relative price, denoted in the same way as the previous section, but with an asterisk, would be:

$$
\tilde{p}_{0}^{*}=\frac{\left((1+\sigma) p_{2}^{\prime}+\phi\right)}{\left(p_{1}^{\prime}+\phi\right)(1+\varepsilon)}
$$

Applying VAT only to real consumption would lead to the following relative price:

$$
\tilde{p}_{1}^{*}=\frac{\left((1+\tau+\sigma) p_{2}^{\prime}+\phi\right)}{\left((1+\tau) p_{1}^{\prime}+\phi\right)(1+\varepsilon)}
$$

Where $\tilde{p}_{0}^{*} \neq \tilde{p}_{1}^{*}$.

If VAT is applied to real consumption and explicit fees and commissions, it leads to:

$$
\tilde{p}_{2}{ }^{*}=\frac{\left((1+\tau+\sigma) p_{2}+(1+\tau) \phi\right)}{\left((1+\tau) p_{1}^{\prime}+(1+\tau) \phi\right)(1+\varepsilon)}
$$

Unlike Jack's model, in this scenario:

$$
\tilde{p}_{0}{ }^{*} \neq \tilde{p}_{2}{ }^{*}
$$

Nonetheless, applying VAT to all (explicit and implicit) charges from banks, at the same tax rate as the rest of goods:

$$
\tilde{p}_{3}{ }^{*}=\frac{(1+\tau)(1+\sigma) p_{2}^{\prime}+(1+\tau) \phi}{\left((1+\tau) p_{1}^{\prime}+(1+\tau) \phi\right)(1+\varepsilon)}
$$

Fulfilling:

$$
\tilde{p}_{0}{ }^{*}=\tilde{p}_{3}{ }^{*}
$$

Considering a different tax rate for real and financial consumption, we obtain:

$$
\tilde{p}_{4}{ }^{*}=\frac{\left(\left(1+\tau_{R}+\left(1+\tau_{F}\right) \sigma_{R}\right) p_{2}^{\prime}+\left(1+\tau_{F}\right) \phi\right)}{\left(\left(1+\tau_{R}\right) p^{\prime}{ }_{1}+\left(1+\tau_{F}\right) \phi\right)(1+\varepsilon)}
$$

Which fulfills $\tilde{p}_{0}{ }^{*}=\tilde{p}_{4}{ }^{*}$ if, and only if, $\tau_{R}=\tau_{F}$.

Therefore, according to the proposed approach, all fees and commissions charged by financial institutions on banking services, both explicit and implicit as spreads, should be taxed under VAT, and the tax rate should be the same as that applied to other goods and services. This would be a first best for the economy, but currently many countries already tax financial institutions by levying labor and capital income, but no VAT is applied to these services. Therefore, there could be a double taxation if banking services were taxed on VAT. In spite of that, the rest of sectors also suffer from a double taxation (capital and labor incomes are levied together with the value added, e.g. the Corporate Income Tax). Hence, treating the financial sector differently (without double taxation) from the other sectors (double taxed) would distort the economy, presumably generating more inefficiencies than with this second best that allows a general double taxation for all sectors in a similar, not distortionary, way. The first best would be, obviously, taxing all sectors with income or value added taxes as Auerbach and Gordon (2002) suggest.

Another suggestion of our model is the fact that there could be value added in banking services without necessarily incurring in real costs. The best example, we think, is the value added generated by some Internet-based financial services, where real resources used in the production of the services are almost insignificant but value added is generated. Hence, we attribute this value added to the satisfaction of intangible needs of the consumers as security in the accounts, the immediacy and availability of money or the need of maintaining a specific purchase power that cash does not allow, which can be considered non-real or financial inputs.

Finally, it is worth to mention that the satisfaction of these needs leads consumers to reduce their budget constraint, and hence, to reduce the potential purchases of real goods and services 
in order to pay for the banking services. This payment would be the price of these banking services, which would be the value-added generated by the financial sector for each transaction. This value added is, according to the Cash-Flow method developed by English and Poddar (1997), the difference between the interest without fees and commissions (pure interest) and the saving interests, for savings, and the difference between the lending interest and the pure interest, for loans. Nonetheless, in a multi-activity complex financial sector it could be difficult to differentiate among the implicit margin for each transaction, or even between traditional banking spreads from the total spread.

\section{Concluding remarks}

The issue of the taxation of the value added of banking services under VAT is a key issue for the efficiency of the tax system. This topic has generated a great deal of debate for more than two decades, as less distorting methods of taxation are sought, but there is still no consensus. Auerbach and Gordon (2002) analytically show that all primary inputs included for producing a good should be taxed, which is right even for financial services. They explicitly treat the costs of financial transactions but only considering real inputs, not non-real inputs as safety or liquidity. Jack (2000) developed a model suggesting banking spreads should not be taxed, but explicit fees should be taxed at the same tax rate as the rest of goods and services. We propose an alternative model in which all banking charges of traditional saving-lending services, both spreads and explicit, should be taxed under VAT at the same tax rate as real consumption Our proposal could also consider non-real inputs and therefore Internet-based banking services with irrelevant real inputs.

\section{Acknowledgements}

The author expresses his gratitude for the funding received from the Regional Government of Aragon European Social Fund and the European Regional Development Fund (Public Economics Research Group). I would like to acknowledge Julio López-Laborda for his help to write the paper.

\section{References}

Adam, S., Besley, T., and Blundell, R. (2011) Tax by design: The Mirrlees review, Oxford University Press, New York.

Auerbach, A. J., and Gordon, R. H. (2002) Taxation of Financial Services under a VAT, American Economic Review, 92(2), 411-416.

English, M., and Poddar, S. (1997) Taxation of Financial Services under a Value-Added Tax: Applying the Cash-Flow Approach, National Tax Journal, 50(1), 89-111.

Gillis, M. (1990) The VAT and Financial Services", in M. Gillis, C. S. Shoup and G. P. Sicat (Eds.), Value Added taxation in developing countries, 83-94, Washington DC, World Bank.

Hoffman, L. A., Poddar, S. N., and Whalley, J. (1987) Taxation of Banking Services under a Consumption Type, Destination Basis VAT, National Tax Journal, 40(4), 547-554.

IMF (2010) A Fair and Substantial Contribution by the Financial Sector", Final Report for the G20, IMF, Washington DC, available at http://www.imf.org/external/np/g20/pdf/ 062710b .pdf.

Jack, W. (2000) The Treatment of Financial Services under a Broad-Based Consumption Tax, National Tax Journal, 53(4), 841-851.

Keen, M. (2011) Rethinking the Taxation of the Financial Sector, CESifo Economic Studies, 57(1), 1-24. 
Keen, M., Krelove, R., and Norregaard, J. (2016) Policy Forum: “The Financial Activities Tax", Canadian Tax Journal, 64(2), 389-400.

Lockwood, B., and Yerushalmi, E. (2014) Should transactions services be taxed at the same rate as consumption?, Oxford University Centre for Business Taxation Working Paper, $14 / 23$, Oxford, UK.

López-Laborda, J., and Peña, G. (2017) International Practices of Financial VAT, International VAT Monitor, 28(6), 457-465.

López-Laborda, J., and Peña, G. (2018) A New Method for Applying VAT to Financial Services, National Tax Journal, 71(1), 155-182. 